\title{
ЛІТЕРАТУРОЗНАВСТВО
}

УДК 39(477)(092)

Валентина Гончарук

(Умань, Україна)

\section{ФОЛЬКЛОРНО-ЕТНОГРАФІЧНА СПАДЩИНА УКРАЇНИ У КНИЗІ П. ЧУБИНСЬКОГО «МУДРІСТЬ ВІКІВ»}

У статті прослідковано шлях становлення П. П. Чубинського як ученого, який удосконалив справу збирання та опрацювання фольклору й етнографії на науковій основі, створив потужну базу для фольклорно-етнографічних студій багатьох наступних поколінь дослідників. Очолювана ним етнографічно-статистична експедичія 1869-1870 років була найвидатнішим явищем в історії тогочасної етнографії. Вражає кількість зафіксованих дослідником скарбів народної культури, які він умістив у сім томів (дев'ять книг) «Праць етнографічно-статистичної експедииії в Західно-Руський край» (1872-1879).

Частина матеріалів «Праџь...» П. Чубинського увійила до книги «Мудрість віків», яку було видано 1995 року. Кожен дослідник фольклорно-етнографічної спадшини українців може знайти у ній записані автором у різних регіонах Украӥни звичаї та обряди, морально-етичні традиції, уявлення $і$ вірування, календарнообрядовий і родинно-побутовий фольклор.

Ключові слова: фольклорно-етнографічна спадщуина України, Павло Чубинський, етнографічно-статистична експедиція, книга «Мудрість віків», звичаї та традиії, уявлення і вірування, календарна і сімейна обрядовість.

Гончарук В. Фольклорно-этнографическое наследие Украины в книге П. Чубинского «Мудрость веков».

В статье прослежен путь становления П. П. Чубинского как ученого, который усовершенствовал дело собирания и обработки фольклора и этнографии на научной основе, создал мощную базу для фольклорно-этнографических исследований многих последующих поколений исследователей. Возглавляемая им этнографическистатистическая экспедиция 1869-1870 годов была выдающимся явлением в истории этнографии того времени. Поражает количество зафиксированньх исследователем сокровищ народной культуры, которые он вместил в семь томов (девять книг) «Трудов этнографически-статистической экспедиџии в Западно-Русский край» (1872-1879).

Часть материалов «Трудов ...» П. Чубинского вошла в книгу «Мудрость веков», которая была издана в 1995 году. Каждый исследователь фольклорноэтнографического наследия украинцев может найти в ней записанные автором в разных регионах Украины обычаи и обряды, морально-этические традиции, представления и верования, календарно-обрядовый и семейно-бытовой фольклор.

Ключевые слова: фольклорно-этнографическое наследие Украины,, Павел Чубинский, этнографически-статистическая экспедиция, книга «Мудрость веков», обычаи и традищии, представления и верования, календарная и семейная обрядность. 
Honcharuk $V$. Folklore and ethnographic heritage of Ukraine in the book «Wisdom of the ages» by Pavlo Chubynskyi.

In the tragic history of Ukrainoznavstvo there are only a few names that could be put next to the name of Pavlo Chubynskyi. Only one poem «Ukraine is still alive» made his name immortal forever. Scientist recorded everything that respondents had stored in their memory: different genres of folklore, games, dances, songs, ideas, beliefs, superstitions, customs and rituals.

Pavlo Chubynskyi had dedication and efficiency, great energy and talent for collecting and research work and outstanding ability to collect around all the supporters. Ethnographical-statistical expedition, headed by him, was the most prominent event in the history of ethnography of the $19^{\text {th }}$ century. The number of recorded folk culture treasures is very impressive and it was collected in seven volumes (nine books), "Proceedings of ethnographical-statistical expedition in West Rus land» that came out in St. Petersburg in 1872-1879. Based on "Proceedings of ethnographical-statistical expedition in West Rus land» was published the book «Wisdom of the Ages» in 1995, which included mythology, ideas and beliefs, folk calendar, rites and customs, calendar and family rites.

All this rich folklore and ethnographic heritage of Ukraine that was captured by Pavlo Chubynskyi should actively be in use in educational process of all educational institutions, as well as in Ukrainian family educational practice.

Keywords: folklore-ethnographic heritage of Ukraine, Pavlo Chubynskyi, Ukrainoznavstvo, "Wisdom of the Ages», statistical and ethnographic expedition, ideas and beliefs, calendar and family rites.

Постановка наукової проблеми та ї̈ значення. У славетній історії українознавства зовсім небагато імен, які можна було би поставити поряд 3 ім'ям Павла Чубинського. Павло Платонович Чубинський відомий у науковому світі як етнограф, фольклорист, економгеограф (на той час статист), поет, автор гімну України.

На середину XIX - початок XX ст., час значного національного піднесення в Україні, припадає формування народознавства як науки. Фольклорно-етнографічні праці цього періоду є класичним зводом всього накопиченого фонду знань про традиційну народну культуру. Основу для їх систематизації заклали такі визначні дослідники, як В.Гнатюк, М. Драгоманов, П. Єфименко, П. Іванов, В. Милорадович, П. Чубинський, М. Сумцов і багато інших. За кількістю зробленого, за новизною підходів iз етнографії, праці П. Чубинського не мають відповідників у тогочасній науці. Написання їх на багатій джерельній основі, використанням значного порівняльного матеріалу, дозволили вченому створити своєрідний енциклопедичний посібник з народної духовної і матеріальної культури українців («Праці етнографічно-статистичної експедиції в Західно-Руський край» [10], частина матеріалу 3 яких увійшла до книги 3 2-х частин «Мудрість віків. Українське народознавство у творчій спадщині Павла Чубинського») [8; 9].

Ознайомлення 3 біографією визначного дослідника викликає шанобливе ставлення до цієї мужньої, неспокійної та невтомної людини. 
Павло Чубинський вирізнявся цілеспрямованістю і діловитістю, великою енергією та хистом до «унесипущої» праці, а також неабияким умінням групувати навколо себе однодумців [7, с. 5].

Тотальний наступ імперської політики, асиміляції всіх націй - це умови, в яких довелося жити й працювати П. Чубинському. Але, незважаючи на придушення українського слова, української культури, у середовищі української інтелігенції пробуджується інтерес до своєї минувшини [5, с. 97].

На жаль, сьогодні очевидним $є$ факт недостатнього заглиблення дослідників у творчу лабораторію вченого, розрізненість нарисів біографічного плану. Отже, нині існує нагальна потреба в докладному та всебічному вивченні життєвого i творчого шляху П. Чубинського, належному поцінуванні його наукового доробку («Праць етнографічностатистичної експедиції в Західно-Руський край», книги «Мудрість віків»).

Аналіз останніх досліджень і публікацій. Схвальну оцінку працям П. Чубинського давали в різний час українські та російські вчені, зокрема

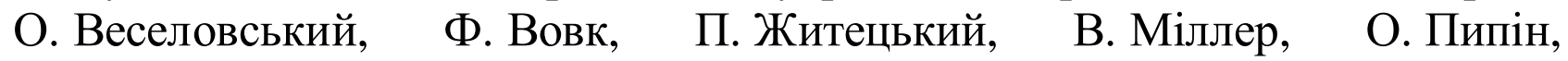
М. Сумцов, І. Франко та ін.

Життя і творчу діяльність П. Чубинського досліджували Я. Верменич, М. Галюк, Л. Гудзенко, С. Єфремов, І. Коляда, О. Остапенко, В. Панченко, Ф. Погребенник, О. Рутковська, Г. Скрипник, Д. Чередниченко, С. Шевчук, В. Шпак та ін. Більшість із них відзначила, що видатному вченому належить ініціатива стосовно розширення і завдань експедиції, включаючи вивчення етнографії та фольклору українців, і географічного ареалу дослідження.

Мета і завдання статті. Mema cmammi - розкрити основні досягнення фольклорно-етнографічних експедиційних досліджень П. Чубинського, проаналізувати фольклорно-етнографічний доробок ученого у книзі «Мудрість віків».

Досягнення поставленої мети передбачає виконання таких завдань: з'ясувати спрямування пошуково-експедиційної роботи П. Чубинського; окреслити ареал експедиційних досліджень ученого; розкрити основну тематику, зміст і результати очолюваної ним експедиції; проаналізувати фольклорно-етнографічний матеріал, поданий у книзі «Мудрість віків».

Виклад основного матеріалу й обгрунтування отриманих результатів дослідження.

Науковий доробок П. Чубинського 3 етнографії та фольклору вважаємо справжньою теоретичною базою для подальших досліджень у цих галузях. П. Чубинський як особистість вирізнявся цілеспрямованістю й діловитістю, вмінням групувати довкола себе однодумців. Як добрий організатор він зумів зацікавити фольклорно-етнографічною збирацько- 
дослідницькою діяльністю багатьох видатних діячів, передусім членів Громади, а також учительство, лікарів та священиків.

У 1869 р. Російське Географічне Товариство (РГТ) організувало етнографічну експедицію в «Західно-Руський край» i запросило П. П. Чубинського очолити іiі. Добре усвідомлюючи значущість експедиції, П. Чубинський розробив детальні маршрути, плани, підібрав помічників, обдумав шляхи. 5 спеціальних програм були опубліковані у пресі та розіслані 500 адресатам, які добре знали життя на місцях і могли надати потрібні відомості [2, с. 142].

За період 31869 р. до 1870 р. П. П. Чубинський здійснив три подорожі.

Перша подорож пролягала від Києва до Канева, далі долиною річки Рось по кількох повітах Київщини до Бердичева та Житомира. Звідси уздовж річки Случ через Новоград-Волинський і Староконстянтинівський повіти - в Подільську губернію (Проскурівський, Ушицький та Кам'янець-Подільський повіти). Далі маршрут пролягав на Бессарабію i Польщу, де було охоплено 9 повітів Седлецької та Люблінської губерній і Холмщину. На зворотному шляху П. Чубинський побував у Кременецькому, Дубенському, Володимир-Волинському повітах Волинської губернії, містах Ковелі, Луцьку, Рівному, Овручі, Малині та Радомишлі.

Узимку 1869 року дослідник відвідав Радомишльський повіт Київської губернії, Ковельський, Луцький, Рівненський, Овруцький повіти Волинської губернії і завершив мандрівку в Радомишлі.

Улітку 1870 року разом із I. Чередниченком та В. Кравцем П. Чубинський об'їздив південні повіти Київщини (Черкаський, Звенигородський, Уманський, Сквирський, Чигиринський); Переяславський і Золотоніський повіти Полтавської губернії; Гайсинський, Ольгопільський, Балтський, Ямпільський, Могилівський, Летичівський, Літинський, Вінницький і Брацлавський повіти на Поділлі i завершив свою експедицію у Липовецькому, Сквирському та Васильківському повітах [8, с. 7-8].

Вражає обсяг i глибина дослідницької праці експедиції П. Чубинського, як вражають і ті незліченні скарби народної культури, зібрані в семи томах (дев'яти книгах) «Праць етнографічно-статистичної експедиції в Західно-Руський край», які вийшли в Петербурзі у 1872-1879 роках [4, с. 13]. П. Чубинський записав майже 4000 обрядових пісень, 300 казок, 20 весільних обрядів, у 60 місцевостях зафіксував і опрацював говірки, звичаї, повір'я. 3 книг волосних та земських судів та управ він вибрав тисячі справ, випадків та ухвал, які б вияскравлювали характерні типи взаємовідносин між людьми. Скрізь він фіксував рід та характер занять населення, відмінності в обробітку грунту, народні прикмети. 
Особливу увагу вченого привертали головні події людського життя народження, одруження, проводи в рекрути, смерть людини. Завдяки експедиції П. Чубинського збереглися матеріали про стан торгівлі у різних місцевостях, бджолярства, тютюнництва, виноробства, шовківництва, броварства [6].

До часу П. Чубинського не було фундаментальних праць з етнографії України. Зазвичай дослідники вивчали лише одне етнографічне явище та ще й не робили спроб якось узагальнити чи систематизувати записаний уривчастий матеріал. Учений же зібрав у багатьох регіонах України та систематизував у своїх «Працях...» матеріал, який відображав різноманітні сторони народного життя, явища традиційної народної культури українців, надаючи можливість кожному звернути увагу на їх регіональні особливості.

Блискуче проведення експедиції зробило ім'я Чубинського відомим i авторитетним в офіційних наукових колах і дозволило йому домогтися від уряду створення Південно-Західного відділу Російського Географічного товариства в Києві, який відіграв визначну роль у збиранні, дослідженні й популяризації фольклорних, історичних, етнографічних та археологічних пам'яток на території України [1, с. 10].

Щодо наукової цінності «Праць...», то іiі наочним підтвердженням стало присудження П. Чубинському «за особенную деятельность и неусыпные труды» [3, с. 15] в 1879 році золотої медалі Міжнародного конгресу в Парижі й цього ж року - Уваровської премії Петербурзької Академії наук.

1995 року вийшла у світ книга «Мудрість віків» (у двох частинах), яка увібрала в себе частину обширу творчої спадщини видатного вченого: вірування, народний календар, звичаї, традиції, обрядовість, фольклор [8, 9].

Матеріал I частини книги «Мудрість віків» [8] подано під загальним заголовком «Вірування $\boldsymbol{i}$ повір'я» і розбито на окремі глави. У 1-ій главі знаходимо уявлення, вірування і повір'я про небесні світила та різні атмосферні явища: небо, сонце, місяць і його фази, затемнення сонця i місяця, зірки, Молочний Шлях, зміну дня і ночі та пір року, падаючі зірки, падаючі камені, комети, стовпи і круги (навколо сонця та місяця), грім і блискавку, туман, дощ, райдугу, град, сніг, мороз, іній, вітер, вихор. 2-га глава вміщує вірування і повір'я про землю, вирій, гори, яри, кургани, море, воду, вогонь, вогники та маячення.

У 3-ій главі «Царство тварин» читач ознайомлюється з безцінними відомостями, записаними з уст народу: про диких звірів і домашніх тварин (волів і ослів, рогату худобу, коня, козу, свиню, мавпу, ведмедя, вовка, собаку, кота, мишу звичайну і кажана, дику козу, зайця, ласку, крота, ін.) та про способи лікування домашніх тварин; про птахів (курку, пав i 
павичів, ластівку, горобця, зозулю, дятла, сороку, чайку, журавля і диких гусей, лелеку, яструба, сову, орла, крука, голуба, солов'я та ін.); про «гадів» (гадюку, вужа, жабу, черепаху); про риб (щуку, камбалу i «однобоку рибу»); про комах (саранчу, черв’яка, цвіркуна, мурашок, павуків, бліх, вошей і ін.). Також він може використати у своєму житті подані у цій главі зразки замовлянь, які стосуються тварин, молитви «к пчелам относящиеся» та замовляння до бджіл.

4 глава «Царство рослин» подає нам уявлення та вірування про різні дерева (сосну, осику, липу, дуба, березу, бузину та ін.); про різні рослини (папороть, очерет, коров'як, осот, любисток, полин, барвінок, чорнобривці, пшеницю i жито, ячмінь і горох, просо, огірки, цибулю, часник, ін.) та наводить тексти замовлянь, які стосуються рослин.

У 5 главі «Людина» можемо знайти інформацію, записану автором від старших респондентів, про частини людського тіла (зуби, брови, руки, нігті, ноги, п’яти) та про різноманітні дії (умивання, носіння палиці, чхання, гостювання, благословення батьків, сни, присяга та ін.). Ця ж глава вміщує тексти замовлянь, які використовувалися у різноманітних життєвих ситуаціях, як-от «Од себе заговорювать», до суду, любовні та ін.

Під заголовком «Житло, господарські будівлі, знаряддя $i$ начиння» подаються вірування i повір'я, пов'язані 3 хатою, іiі різноманітними частинами, меблями, а також із знаряддями (вікно, поріг, ключі, стіл, віник, кочерга, помело, мотовило, веретено, кварта, каганець, ін.); 3 господарсько-виробничими об’єктами двору (погріб, «сарай», млин); із таким господарським знаряддям, як віз; iз хліборобським інвентарем (плуг, рало, соха, борона, сані, ваги та ін.).

У цій главі знаходимо повчальну інформацію про традиційний одяг, їжу та посуд для неї, звертаємо увагу на подане народне розуміння хвороб, їх назви (несплячки, жовтуха, «куряча сліпота», «бешиха» або рожа, чорна хвороба, лихорадка, «волос», «підвій», «уроки» та ін.) і способи їх лікування.

6 глава «Світ духовний» із народної точки зору пояснює, звідки узявся світ, як було створено людину, подає тексти пісень про Адама і Сву та про душу, уявлення про чортів, відьом, упирів, вовкулаків, мавок, русалок, ворожбитів, чарівників і ін., різні тлумачення уособлень (долі, смерті, рахманів і ін.), уявлення про перетворення. Також ця глава ознайомлює нас із народним розумінням Бога-Батька, його сина Iсуса Христа і Божу Матір, святих Петра і Павла, Миколая, Георгія та ін.

II частину книги «Мудрість віків» [9] розпочинає розділ «Календар народних звичаӥв $\boldsymbol{i}$ обрядів», у якому описується порядок виконання українцями обрядодій упродовж усього календарного року, починаючи від 1 січня, на Святого Василя, і закінчуючи 31 грудня, на «Меланки» (за ст. ст.). 
Кожному знадобляться знання з наступних розділів II частини книги, у яких ідеться про родинні та інші важливі події в особистому житті людини (народження дитини, хрестини, зливки, весілля, похорони). Тут же наводяться записані тексти колискових пісень, дитячих ігор, а також матеріали, що ознайомлюють із способами народного лікування дітей i вагітних жінок. Найбільш детально описано народне весілля з обрядовим пісенним супроводом, повір'ями, табу й пересторогами, побажаннями та ритуальними словесними формулами. Завершують II частину книги загадки, розміщені за алфавітом, про різноманітні явища та предмети побуту.

Висновки та перспективи подальшого дослідження. Отже, П. Чубинський під час експедицій здійснив широкомасштабні фольклорно-етнографічні дослідження в різних регіонах України. Завдяки неабияким старанням ученого було підготовлено до друку сім томів (дев’ять книг) «Праць етнографічно-статистичної експедиції в ЗахідноРуський край», частина матеріалу з яких стала основою книги «Мудрість віків»: родинна та календарна обрядовість, фольклор, вірування і повір'я, житло, одяг, їжа, заняття та промисли, побут, дозвілля. Весь матеріал цієї книги складає неоціненну фольклорно-етнографічну спадщину України, яка потребує подальшого опрацювання й дослідження.

\section{СПИСОК ВИКОРИСТАНОЇ ЛІТЕРАТУРИ}

1. Верменич, Я. Павло Чубинський - народознавець і автор слів національного гімну «Ще не вмерла Україна» / Я. Верменич // Українська мова і література в школі. - 1992. - № 3. - С. 9-11.

2. Горленко, В. Ф. 3 історії українських етнографічних та російсько-українських етнографічних зв'язків / В. Ф. Горленко. - К. : Наук. думка, 1964. - 248 с.

3. Джус, В. Невідомий Павло Чубинський / В. Джус // Закон і бізнес. - 1999. № 22. - C. 15 .

4. Коляда, І. П. П. Чубинський: штрихи до історичного портрету (до 135-ї річниці заснування Південно-Західного відділу Імператорського Російського географічного товариства) / І. Коляда // Історія в школі. - 2008. - № 4. - С. 1217.

5. Остапенко, О. Наукова спадщина Павла Чубинського: вивчення і збереження / О. Остапенко // Народна творчість та етнографія. - 2000. - № 4. - С. 97-102.

6. «Сила чорноземна наш Чубинський...». 170 років від дня народження українського етнографа, фольклориста, поета, громадського діяча, автора слів Гімну України - [Електронний ресурс] // - Режим доступу: http://ukrfoto.net/rus/people_41.html.

7. Скрипник, Г. Народознавча спадщина П. Чубинського 3 погляду сучасної етнології / Г. Скрипник // Народна творчість та етнографія. - 2009. - № 2. C. 4-23.

8. Чубинський, П.П. Мудрість віків: народознавство у творчій спадщині П. Чубинського. Кн. 1 / П. П. Чубинський. - К. : Мистецтво, 1995. - 222 с. 
9. Чубинський, П. П. Мудрість віків: народознавство у творчій спадщині П. Чубинського. Кн. 2 / П. П. Чубинський. - К. : Мистецтво, 1995. - 222 с.

10. Чубинский, П. Труды этнографическо-статистической экспедиции в ЗападноРусский край / П. Чубинский. - Т. I-VII. - СПб, 1872-1878.

Стаття надійшла 20.02.2016 року

УДК 821.161 .2

Оксана Денисюк

(Умань, Україна)

\section{ОБРАЗ КОБЗАРЯ В РОМАНІ «ЗВИЧАЙНИК» Л. МУСІХІНОЇ: ТРАДИЦІЯ ТА ЛІТЕРАТУРНЕ БАЧЕННЯ}

У статті проаналізовано роман Лілії Мусіхіної «Звичайник», який віднесено до так званий «старосвітських романів». Автор статті проводить паралелі між етнографічними матеріалами, зібраними дослідниками XVIII - початку XX ст., $i$ баченням письменницею образу кобзаря Мартина та його поводиря - Устимку.

Ключові слова: кобзар, поводир, сакральність, бідність, мобільність, сліпота, зв'язок з культом померлих, сила молитви.

Денисюк О. Образ кобзаря в романе «Звичайник» Лилии Мусихиной: традиция и литературное видение.

В статье проанализирован роман «Звичайник» Лилии Мусихиной, который относится к так называемым «старосветским романам». Автор статьи проводит параллели между этнографическими материалами, собранными исследователями XVIII - начала XX в., и видением писательницей образа кобзаря Мартына и его поводыря - Устима.

Ключевые слова: кобзарь, поводырь, сакральность, бедность, мобильность, слепота, связь с культом мертвых, сила молитвы.

Denysyuk O. The image of kobzar in novel «Zvychainyk» by Liliia Musikhina: traditions and literary vision.

The author of the article analyzed the novel «Zvychainyk»by Lyliia Musikhina. That novel was referred to the so-called «secular old-novels». The researcher draws parallels between ethnographic materials collected in the XVIII - beginning of the XX century and vision of the writer of image kobzar Martyn and his eyed boy-Ustym.

Image of kobzar could be seen in the dynamics of its development from simple blind old man to God. At the same time the image of boy Ustymis analyzed. He is «difficult» child, with talent to perform the music, the child who cans «sees by heart».

Keywords: kobzar, eyed boy, sacredness, poverty, mobility, blindness, connection with the cult of dead, the power of pray.

У сучасну культуру повертається мистецтво кобзарів та лірників. Дедалі більше уваги наших сучасників привертає це давнє й унікальне 